\title{
Maternal Environment Effect of Warming and Eutrophication on the Emergence of Curled Pondweed, Potamogeton crispus L.
}

\author{
Chao Li ${ }^{1}$, Tao Wang ${ }^{1}$, Min Zhang ${ }^{1, *}$ and Jun $\mathrm{Xu}^{2, *}$ \\ 1 College of Fisheries, Freshwater Aquaculture Collaborative Innovation Center of Hubei Province, \\ Hubei Provincial Engineering Laboratory for Pond Aquaculture, Huazhong Agricultural University, \\ Wuhan 430070, China; chaoli0032@163.com (C.L.); waaqgr@163.com (T.W.) \\ 2 Institute of Hydrobiology, Chinese Academy of Science, Wuhan 430072, China \\ * Correspondence: zhm7875@mail.hzau.edu.cn (M.Z.); xujun@ihb.ac.cn (J.X.)
}

Received: 11 August 2018; Accepted: 17 September 2018; Published: 19 September 2018

\begin{abstract}
Maternal effects may play an important role in life history and offspring performance of aquatic plants. Performance and response of maternal and offspring aquatic plants can affect population dynamics and community composition. Understanding maternal effect can help to fill a gap in the knowledge of aquatic plant life cycles, and provide important insights for species' responses to climate change and eutrophication. This study showed that maternal warming and eutrophication significantly affected the early life stages of curled pondweed, Potamogeton crispus, a submerged macrophyte. Propagule in warmed condition had higher germination percentages and a shorter mean germination time than those under ambient conditions. However, propagule germination in phosphorus addition treatment was inhibited due to the negative effect of eutrophication, e.g., phytoplankton competition and deteriorated underwater light. Meanwhile, elevated temperature led to a decrease of total nitrogen concentrations and an increase of carbon: nitrogen ratios in plant tissues, which may suggest that $P$. crispus will allocate more nutrients to propagules in order to resist the adverse effects of high temperature. A subsequent germination experiment in the same ambient condition showed that maternal warming promoted seedling emergence in contrast to maternal phosphorus addition. Consequently, global warming could modify population growth via maternal environmental effects on early life histories, while increased anthropogenic nutrient inputs may result in a decreased submerged macrophyte. These maternal effects on offspring performance may change competition and the survival of early life-history stages under climate warming and eutrophication through changing the ecological stoichiometry of plant tissue.
\end{abstract}

Keywords: submerged macrophyte; climate warming; eutrophication; germination; maternal environment

\section{Introduction}

Submerged macrophytes play an important role in maintaining the ecological function of shallow lakes by providing food and refuge for organisms living in the water, stabilizing sediments and also are intimately involved in nutrient cycling [1-3]. Therefore, submerged macrophytes are of central importance to stabilize the health of shallow lake ecosystems [4]. Under the global warming envelope [5], submerged macrophytes are considered to be one of the particularly vulnerable communities in aquatic ecosystems [6,7]. Both field and mesocosms studies indicate that early warming will lead to a longer life strategy, higher coverage and biomass of submerged macrophytes [8-10].

However, climate warming will not act in isolation [11], but will interact with eutrophication [12]. Eutrophication has become a major water quality issue in the world [13], and numerous studies 
have shown that a high-nutrient loading lake can shift to a turbid state dominated by phytoplankton from a clear-water state dominated by submerged macrophytes [14-16]. Macrophytes rarely win in the competition with phytoplankton in warm lakes, even the concentrations of phosphorus and nitrogen are considerably low [17]. The effect of long-term eutrophication under climate warming on submerged macrophytes varies among lakes, and the theories are still intensely debated [18-21].

Meanwhile, many pieces of knowledge show that environmental factors (e.g., warming, eutrophication) have major impacts on submerged macrophytes carbon $(\mathrm{C})$ and nitrogen $(\mathrm{N})$ stoichiometry. In aquatic and terrestrial plants researches, elevated temperature could either increase or decrease in the tissue content of a particular element [22-24]. Nutrient addition may lead to a decrease of submerged macrophytes' carbon:nutrient ratios due to luxurious uptake of nutrients [25]. Changes in internal stoichiometry in turn can not only reflect biochemical allocations and life history strategies of submerged macrophytes, but also help to understand the potential effects on offspring and their evolution. Maternal nutrient transfer to the propagule during the reproduction period may have remarkable impacts on the early life stages of aquatic plants [26].

Maternal effects refer to the impacts of the mother plant on the offspring performance not only through genes, but also via effects of maternal environment $[27,28]$. Previous studies have shown that maternal environmental factors such as temperature, nutrients and light can affect life stages of offspring [29,30]. For example, maternal phosphorus addition to R. obtusifolius and Pisum sativum can positively affect the germination rate of its seeds [31,32]. Maternal warming can result in higher germination percentages and shorter mean germination time of offspring seeds than those without warming [33]. Such maternal environmental effects have a profound influence on plant life cycles, niche construction and ecosystem evolution [27,34,35]. Maternal effects on terrestrial plants are relatively well studied, however, less is known about the maternal effects on aquatic submerged macrophytes.

Given the importance of submerged macrophytes in maintaining the homeostasis of aquatic ecosystems, examining how maternal environmental warming and eutrophication will affect submerged macrophytes emergence could provide us with a significant contribution to make useful predictions about the future of lake ecosystems. In this study, we used the widespread curled pondweed, Potamogeton crispus, as a model species. Similar to other aquatic plants, turions are the major source of reproduction for P. crispus. The turions form on mother plants in the early summer, and start to sprout as the temperature declines to about $20^{\circ} \mathrm{C}$ in autumn. Seedlings of P. crispus can overwinter in most shallow lakes [36]. In addition, due to the mean temperature increase in winter and spring under global warming, P. crispus may be one of the most vulnerable macrophytes.

Our previous study demonstrated that the emergence and ecological stoichiometry of P. crispus were significantly sensitive to the warming environment [37]. Here, we further took the combining effects of warming and eutrophication into account, and focused more on how maternal environment will affect offspring seedling emergence. To experimentally elucidate the mechanisms, underlying the potential changes in maternal and offspring performance attributes in response to climate warming and eutrophication, we used an experimental mesocosm to examine the effect of maternal warming and eutrophication (i.e. phosphorus enrichment) on maternal generation and its offspring performance. We hypothesized that (1) warming would promote the emergence of seedlings, however, phosphorus addition may increase the competition between macrophyte and phytoplankton; (2) warming and phosphorus would affect ecological stoichiometry of maternal generation; (3) for the same reason, we expected warming and phosphorus addition to have a stronger opposite effect on early the emergence of offspring seedlings.

\section{Materials and Methods}

Two experiments were included in this study. The first was maternal germination conducted in a field mesocosm system to mimic eutrophication and climate warming, and the second was set up to detect maternal effect on offspring seedling emergence in the same environment. 


\subsection{Warming and Eutrophication Effects on Maternal Generation}

This part of the experiment was conducted from 4 February to 11 March in 2014 . In this part, our aims were to figure out the effect of warming and eutrophication on P. crispus emergence and its tissue stoichiometric properties. Twenty-four insulated cylindrical polyethylene mesocosms (diameter $=1.5 \mathrm{~m}$, height $=1.4 \mathrm{~m}$ ) were set up at Huazhong Agriculture University in Wuhan, China $\left(30^{\circ} 29^{\prime} \mathrm{N} ; 114^{\circ} 22^{\prime} \mathrm{E}\right)$. Sediment was collected with a Peterson grab sampler at the top few centimeters

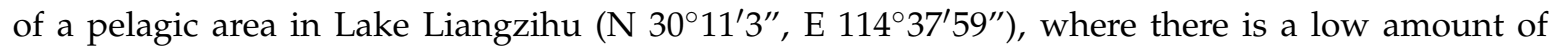
nutrients (TN and TP contents were 0.432 and $0.023 \mathrm{mg} / \mathrm{L}$ ) in lake water and the water is rich with macrophytes. The sediment was loaded into pre-cleaned containers and immediately transported to the experimental mesocosms after being sufficiently mixed. All experimental mesocosms were filled with mixed lake sediments up to $10 \mathrm{~cm}$ high and water up to $1 \mathrm{~m}$ high. Mesocosms water collected from Lake Nanhu (12.5\%) and tap water (87.5\%) (Concentrations of total nitrogen (TN) and total phosphorus (TP) were 3.250 and $0.198 \mathrm{mg} / \mathrm{L}$ in Lake Nanhu) to simulate mesotrophic lake. Prior to water addition, water collected from Lake Nanhu was flushed through a $20 \mu \mathrm{m}$ plankton mesh to remove large fragments of vegetation and to avoid the uncontrolled introduction of zooplankton and vertebrates such as fish or amphibians.

The four treatments consisted of (C) controls mimicking the concurrent state in Lake Liangzihu with respect to temperature and nutrient level; $(\mathrm{T})$ an increase in temperature of $4.5{ }^{\circ} \mathrm{C}$ compared to the control; $(\mathrm{P})$ addition of $50 \mu \mathrm{g} \mathrm{L}{ }^{-1}$ phosphate $\left(\mathrm{KH}_{2} \mathrm{PO}_{4}\right)$ every 2 weeks and mimicking the eutrophication process of Lake Liangzihu; and $(\mathrm{T}+\mathrm{P})$ a combination of both factors, which constituted a future scenario with respect to temperature and phosphorus content. Each of the four treatments was replicated six times. Four treatments were randomly distributed in a $10 \times 20 \mathrm{~m}(\mathrm{~L} \times \mathrm{W})$ area. Treatments with increased temperature were performed by aquarium heaters (1000 W). A water pump was used to mix the water body completely. These mesocosms were controlled by a computer system, which was equipped with sensors at $0.5 \mathrm{~m}$ water depth to measure the temperature in both unheated and heated mesocosms once every second. The control system regulated each temperature-elevated mesocosm individually based on the mean of the controls at each measurement time. During this period, evaporation losses from the mesocosms were replaced with tap water when not compensated for by rainfall.

Maternal germination of $P$. crispus in mesocosms was recorded every week using a waterproof camera (Nikon COOLPIX AW100s, Nikon Corp., Tokyo, Japan) in 2014. The camera was fixed in an equipment with a long rod. Recording in each tank followed a standard procedure according to Zhang et al. [37]. All videos were analyzed in the computer, to read the number of emerged seedlings in each mesocosm.

Each mesocosm was sampled once a week using a Plexiglas tube (length $=1 \mathrm{~m}$, diameter $=70 \mathrm{~mm}$ ) to get an integrated water sample. Three tubes of samples were taken along the diameter of each enclosure, and from this pooled sample, water was taken for analysis of TP, dissolved reactive phosphate (SRP), TN and chlorophyll-a concentrations. Dissolved oxygen (DO), conductivity and pH were measured electronically at the same time with a HACH HQD Portable Meters (HQ60d, HACH, Loveland, CO, USA). Macrophyte samples were taken on 11 May 2014 for total nitrogen (TN) and total carbon (TC) contents determination. After complete drying in the oven at $60^{\circ} \mathrm{C}$ for $48 \mathrm{~h}$, we collected the leaves and stems from each shoot and used a vibration grinding machine (MiniBeadbeater-16, Biospec Products, Bartlesville, OK, USA) to grind the tissues to powder with steel balls vibrating randomly in a freezing tube. About 2 4 mg dry powder was used to detect the carbon and nitrogen content using the $C / N$ element analyzer (Flash EA 1112, Thermo Fisher Scientific, Waltham, MA, USA).

\subsection{Warming and Eutrophication Effects on Offspring Turion}

The purpose of this experiment was to find out whether maternal environment (e.g., warming and eutrophication) will affect the germination percentage to develop the next generation. Propagule used in this part experiment were collected in late December 2014 after the first experiment for each 
mesocosm was finished. Three sediment replicates were dug out from each mesocosm with a PVC pipe (10 cm inner diameter), and washed with a net (pore size $0.25 \mathrm{~mm}$ ) to remove all the mud as a propagule sample. The propagule samples were stored in $4{ }^{\circ} \mathrm{C}$ for germination experiment until spring 2015. The experiment started on 10 February 2015 and ended on 20 March 2015. Before starting offspring seedling, the propagule samples were placed in cylindrical polyethylene containers (height $9.5 \mathrm{~cm}$ and inner diameter $10 \mathrm{~cm}$ ). There were 18 replicates from each treatment in the first experiment, and 72 containers in total for this experiment. The containers were labeled separately according to the four treatments in the first experiment, filled with tap water and placed in the same ambient temperature. The number of emerged seedlings was counted every day in the morning from the first day of the experiment. To prevent influence from filamentous algae we changed the water every week.

\subsection{Data Analysis}

We used a Repeated Measures ANOVA to test the effect of warming and phosphorus addition on both maternal and offspring seedling emergence during the experiment. The effect of treatments on water physicochemical characteristics and tissue TC and TN contents was tested with one-way ANOVA. We used the concentrations of Chl.a and number of emerged seedlings in March 2014 to analyse the correlation. The analyses were performed in SPSS 22.0 (IBM Corp., Armonk, NY, USA).

\section{Results}

\subsection{Water Temperature in Mesocosms}

During our experiment, the average temperature in heated tanks was $4.50 \pm 0.03{ }^{\circ} \mathrm{C}$ higher than ambient temperature mesocosms. The daily average ambient water temperature varied from $3.71^{\circ} \mathrm{C}$ to $12.45^{\circ} \mathrm{C}$. The temperature in the heated mesocosms ranged from $8.17^{\circ} \mathrm{C}$ to $16.9{ }^{\circ} \mathrm{C}$ during the same period (Figure 1).

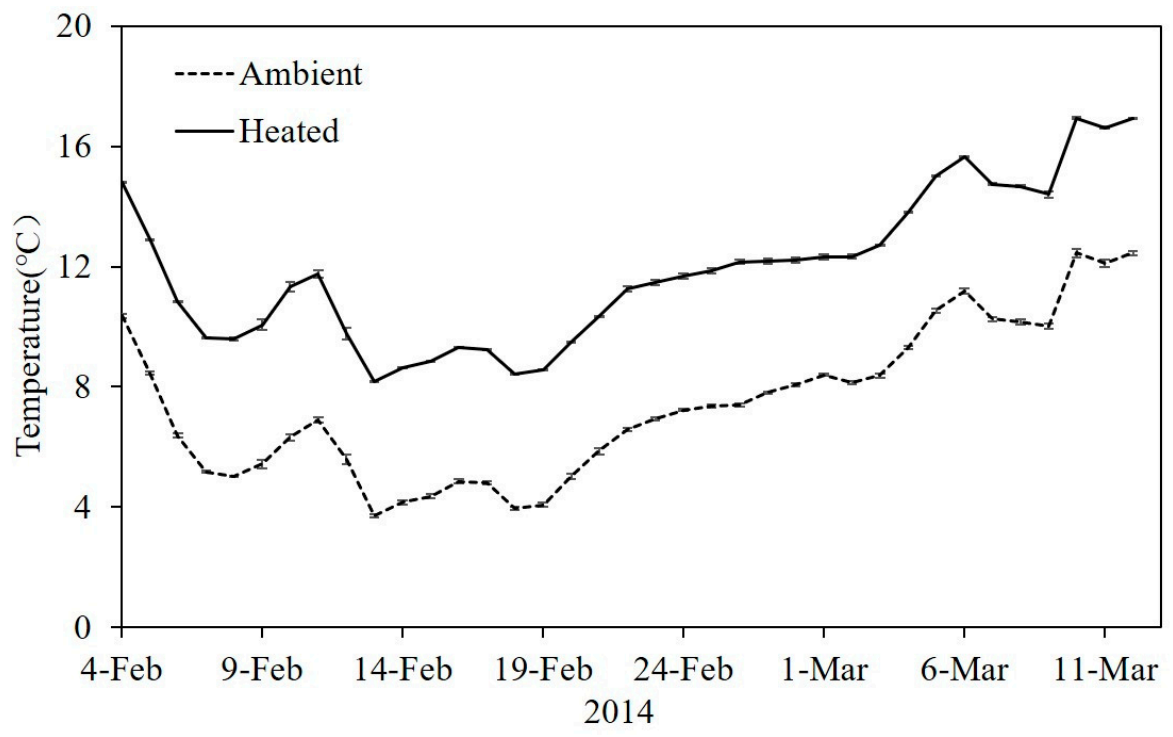

Figure 1. Mean daily temperature in the ambient and heated tanks during the experimental period ( $n=6$ per treatment) in 2014. Data are means \pm standard error (SE).

\subsection{Water Chemistry in Mesocosms}

Average values for DO, $\mathrm{pH}$, Conductivity, TN, TP, SRP and Chl. $a$ in the mesocosms are shown in Table 1. Chl.a concentration $(p<0.01)$ were significantly higher in phosphorus addition treatments. Conductivity $(p<0.05)$ were higher in the heated mesocosms than in ambient ones (Table 1). DO in heated mesocosms was markedly lower than in ambient temperature mesocosms $(p<0.01$, Table 1$)$. 
Table 1. Physicochemical characteristics concentrations in water of all the treatments in 2014. Values are Mean \pm standard error (SE). Abbreviations used: control, C; water temperature was increased $4.5^{\circ} \mathrm{C}$ compared with the control, $\mathrm{T}$; addition of $50 \mu \mathrm{g} \mathrm{L}-1$ phosphate every 2 weeks, $\mathrm{P}$; addition of $50 \mu \mathrm{g} \mathrm{L}{ }^{-1}$ phosphate every 2 weeks and temperature increase of $4.5^{\circ} \mathrm{C}, \mathrm{T}+\mathrm{P}$.

\begin{tabular}{cccccccc}
\hline Treatment & $\mathbf{T P}\left(\mathbf{m g} \cdot \mathbf{L}^{-\mathbf{1}}\right)$ & $\mathbf{S R P}\left(\mathbf{m g} \cdot \mathbf{L}^{-\mathbf{1}}\right)$ & $\mathbf{T N}\left(\mathbf{m g} \cdot \mathbf{L}^{-\mathbf{1}}\right)$ & $\mathbf{D O}\left(\mathbf{m g} \cdot \mathbf{L}^{-\mathbf{1}}\right)$ & $\mathbf{p H}$ & $\begin{array}{c}\text { Conductivity } \\
\left(\boldsymbol{\mu s} \cdot \mathbf{c m}^{-\mathbf{1}}\right)\end{array}$ & $\begin{array}{c}\text { Chlorophyll a } \\
\left(\mathbf{m g} \cdot \mathbf{L}^{-\mathbf{1}}\right)\end{array}$ \\
\hline $\mathrm{C}$ & $0.037 \pm 0.012$ & $0.012 \pm 0.005$ & $2.352 \pm 0.305$ & $12.32 \pm 0.27$ & $8.56 \pm 0.03$ & $227.70 \pm 7.43$ & $2.00 \pm 0.54$ \\
$\mathrm{~T}$ & $0.036 \pm 0.010$ & $0.011 \pm 0.004$ & $2.234 \pm 0.220$ & $10.22 \pm 0.29$ & $8.42 \pm 0.02$ & $265.67 \pm 9.25$ & $2.13 \pm 0.66$ \\
$\mathrm{P}$ & $0.079 \pm 0.020$ & $0.014 \pm 0.006$ & $1.771 \pm 0.380$ & $12.53 \pm 0.22$ & $8.92 \pm 0.12$ & $209.06 \pm 8.27$ & $14.03 \pm 2.47$ \\
$\mathrm{~T}+\mathrm{P}$ & $0.056 \pm 0.009$ & $0.011 \pm 0.004$ & $1.410 \pm 0.221$ & $10.48 \pm 0.45$ & $8.77 \pm 0.12$ & $250.27 \pm 9.76$ & $12.28 \pm 3.37$ \\
\hline
\end{tabular}

\subsection{Emerged Number of P. crispus on Maternal Generation}

The number of emerged seedlings in mesocosms increased significantly in both $\mathrm{T}$ and $\mathrm{T}+\mathrm{P}$ treatments (Figure 2; Repeated measures ANOVA: $\mathrm{F}_{320}=21.28, p<0.001$ ). Maternal warming significantly enhanced the emerged number of P. crispus (Figure $2 ; p<0.001$ ). While phosphorus addition did not show any effect on the emergence of P. crispus, the combined effect of warming and phosphorus addition significantly increased the number of emerged seedlings by $357.78 \%(p=0.002)$. There was a significant negative relationship between the number of emerged seedlings and Chl.a concentration in heated mesocosms (Figure $3 ; p=0.023$ ). However, there was no significant correlate between emerged seedlings and Chl.a in ambient mesocosms.

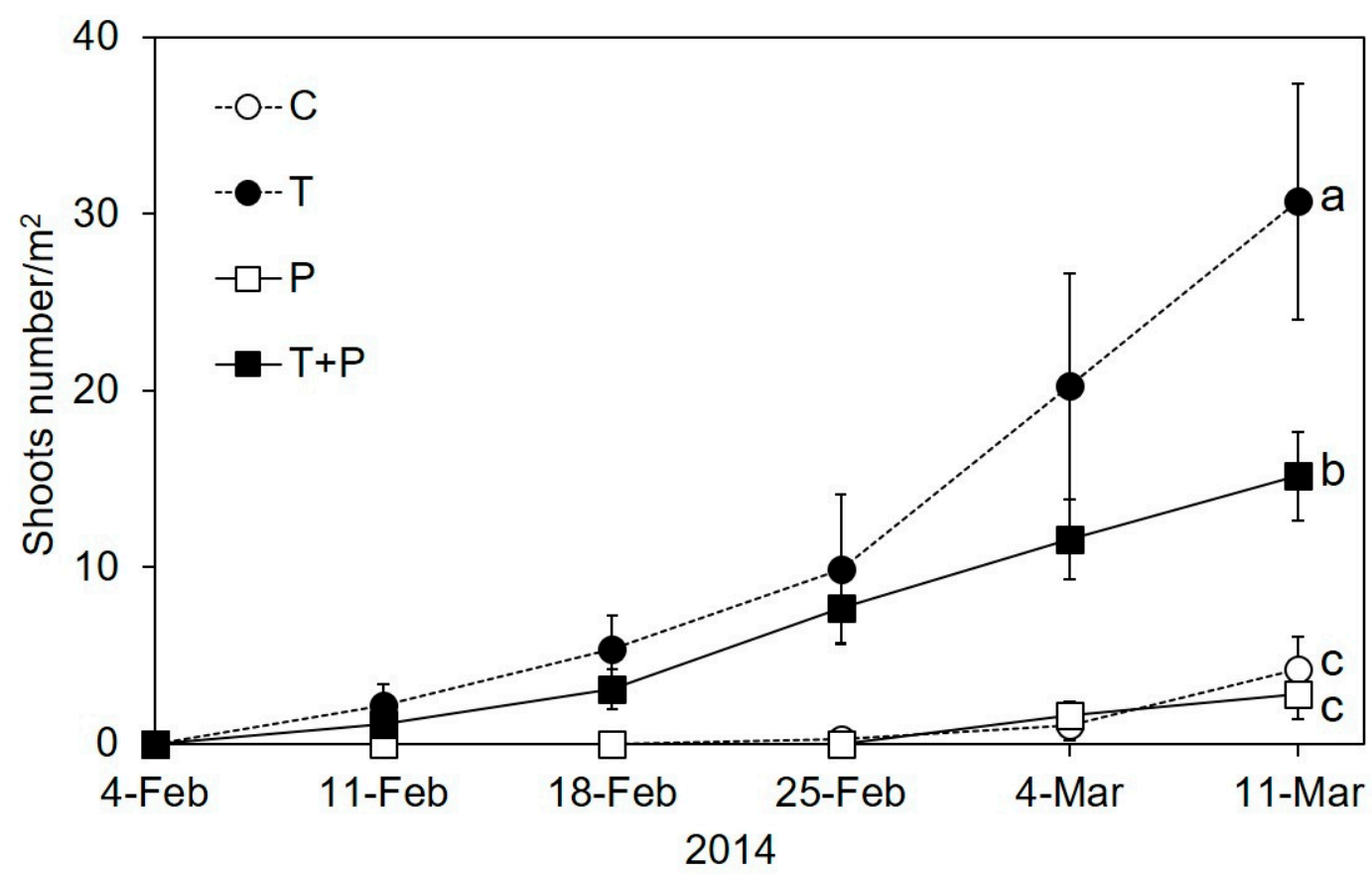

Figure 2. The average number of $P$. crispus shoots during the experiment in 2014. Abbreviations used: control, C; water temperature was increased $4.5^{\circ} \mathrm{C}$ compared with the control, T; addition of $50 \mu \mathrm{g}$ $\mathrm{L}^{-1}$ phosphate every 2 weeks, $\mathrm{P}$; addition of $50 \mu \mathrm{g} \mathrm{L}{ }^{-1}$ phosphate every 2 weeks and temperature increase of $4.5^{\circ} \mathrm{C}, \mathrm{T}+\mathrm{P}$. Different letters $(\mathrm{a}, \mathrm{b}, \mathrm{c})$ indicate significant $(p<0.05)$ differences. Error bars indicate \pm standard error (SE). 

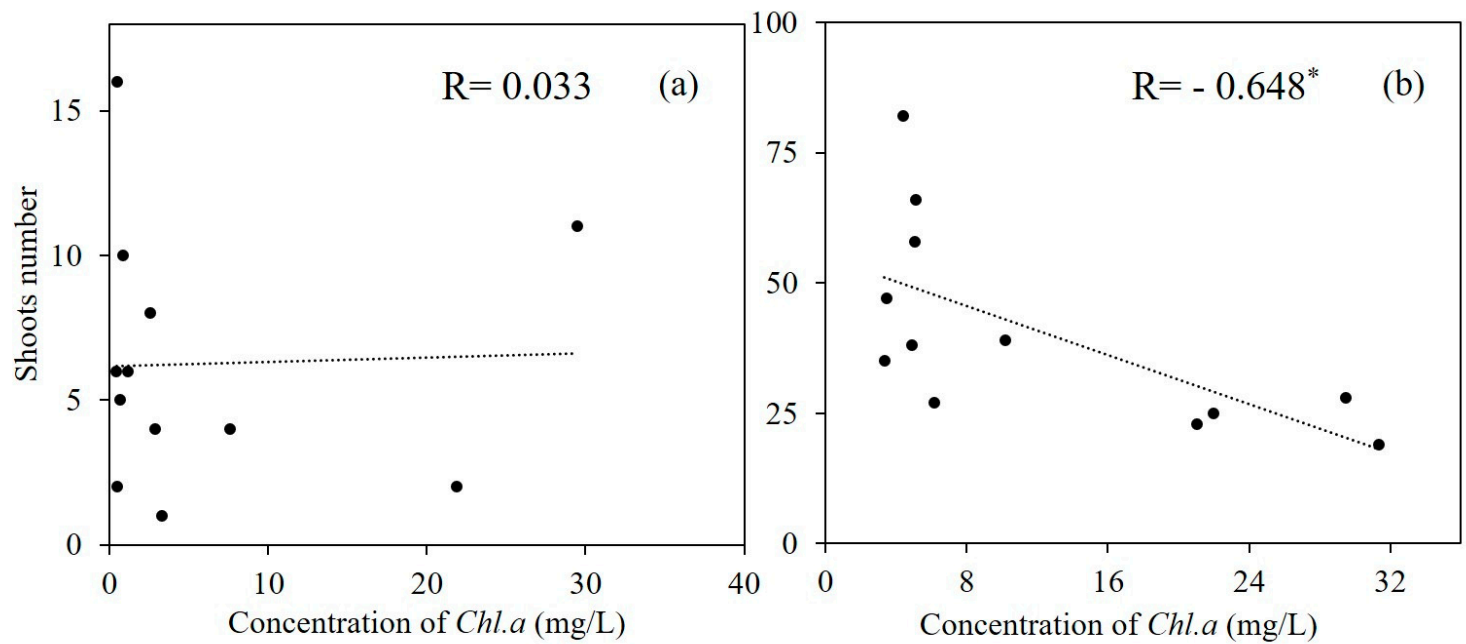

Figure 3. Correlation between concentrations of Chl. $a$ and number of emerged seedlings in March 2014. (a) ambient treatment, (b) heated treatment, ${ }^{*}$ Correlation is significant at the 0.05 level (2-tailed).

\subsection{TC and TN Contents of P. crispus on Maternal Generation}

There was no difference of TC contents in aboveground parts of $P$. crispus between different treatments (Figure 4). However, a decrease of TN contents in tissues was found in $\mathrm{T}$ and $\mathrm{T}+\mathrm{P}$ treatments with increasing temperature (Figure 4; one-way ANOVA: for leaves, $\mathrm{F}_{344}=8.54, p<0.001$; for stems, $\mathrm{F}_{344}=16.57, p<0.001$ ), for leaves changed from $22.58 \mathrm{mg} / \mathrm{g}$ in $\mathrm{C}$ treatment to $17.47 \mathrm{mg} / \mathrm{g}$ in $\mathrm{T}$ treatment and $17.94 \mathrm{mg} / \mathrm{g}$ in $\mathrm{T}+\mathrm{P}$ treatment, and stems dropped from $39.82 \mathrm{mg} / \mathrm{g}$ to $34.30 \mathrm{and}$ $34.14 \mathrm{mg} / \mathrm{g}$ in $\mathrm{T}$ and $\mathrm{T}+\mathrm{P}$ treatments, respectively (for leaves, $\mathrm{T}$ treatment, $p=0.001, \mathrm{~T}+\mathrm{P}$ treatment, $p<0.001$; for stems, $\mathrm{T}$ treatment, $p<0.001, \mathrm{~T}+\mathrm{P}$ treatment, $p<0.001)$. C: $\mathrm{N}$ ratios mirrored total nitrogen, increased with temperature elevated, varying from 9.78 to 11.31 in leaves and from 15.19 to 19.64 in stems in average, while the TC concentrations changed a little with different treatments. 

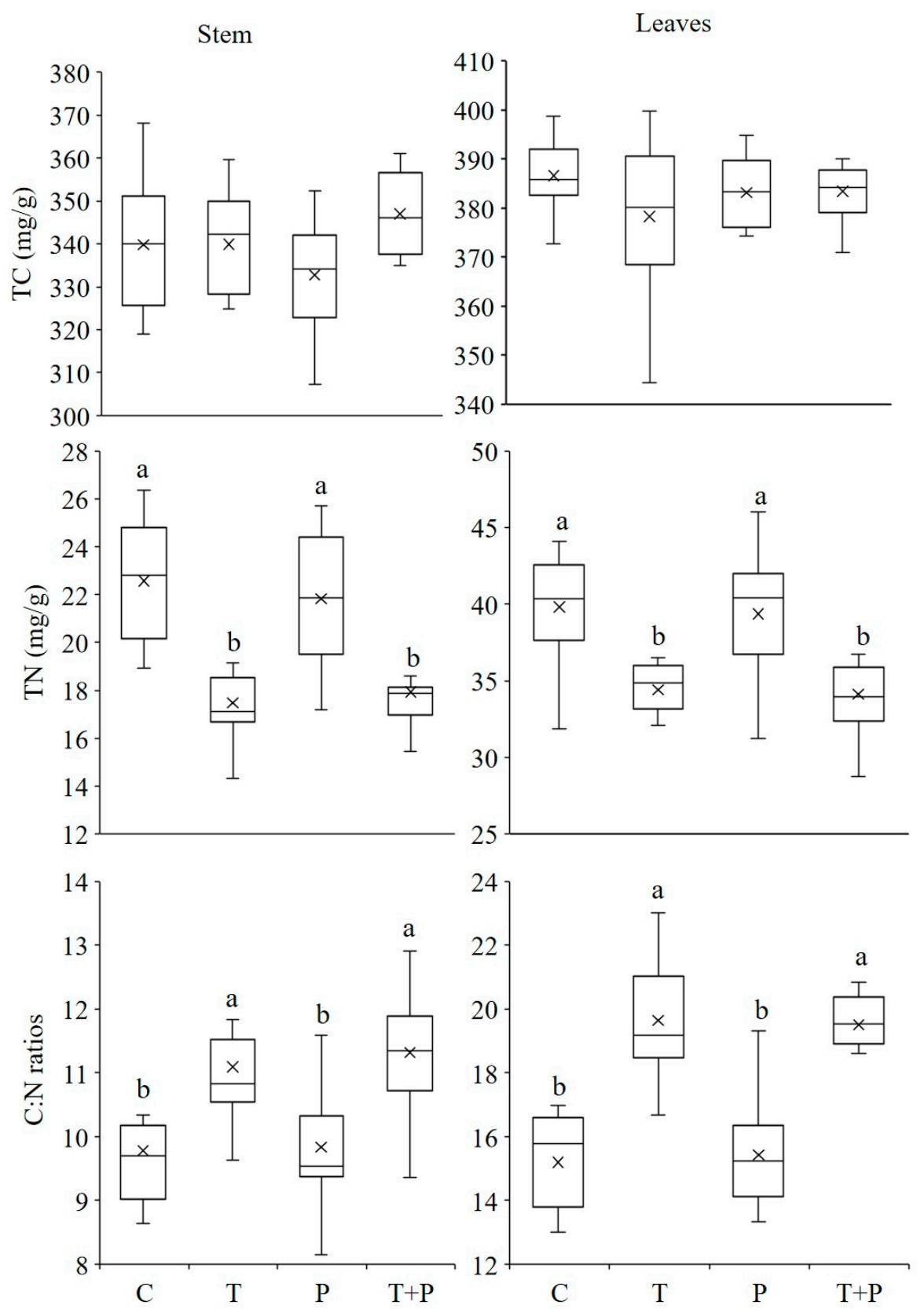

Figure 4. Effect of warming and phosphorus addition on plant total carbon and nitrogen concentrations and carbon: nitrogen ratios in May 2014. Different letters $(a, b, c)$ indicate significant $(p<0.05)$ differences. Error bars indicate \pm standard error (SE). For abbreviations used, see Figure 2.

\subsection{Emerged Number of P. crispus on Offsprings}

As for the offspring performance, no significant difference was found between treatments during the whole experiment (Figure $5, F_{368}=1.753, p=0.164$ ). However, we observed a dramatic emergence of $P$. crispus in $\mathrm{T}$ and $\mathrm{T}+\mathrm{P}$ treatments from day 1 to day 9 , and then the tendency slowed down. Following day 31, no further emergence was recorded (Figure 5). During day 9 to day 20, it was found that average emerged number of $P$. crispus seedlings in T treatments was slightly higher than those in $C$ treatments (Figure $5 ; F_{368}=2.519, p=0.083$ ), and average emerged number of $P$. crispus seedlings in $\mathrm{T}$ treatment were significantly higher than in P treatment $(p=0.02)$. After day 20 , we could only find a slight difference between $\mathrm{P}$ and $\mathrm{T}$ treatments $(p=0.055)$. The germination rate in warming treatments was obviously higher than ambient ones from day 5 to day 20 (Figure 5). In a comparison of all the treatments, the germination rate did not differ significantly from day 21 to the end of this experiment. 


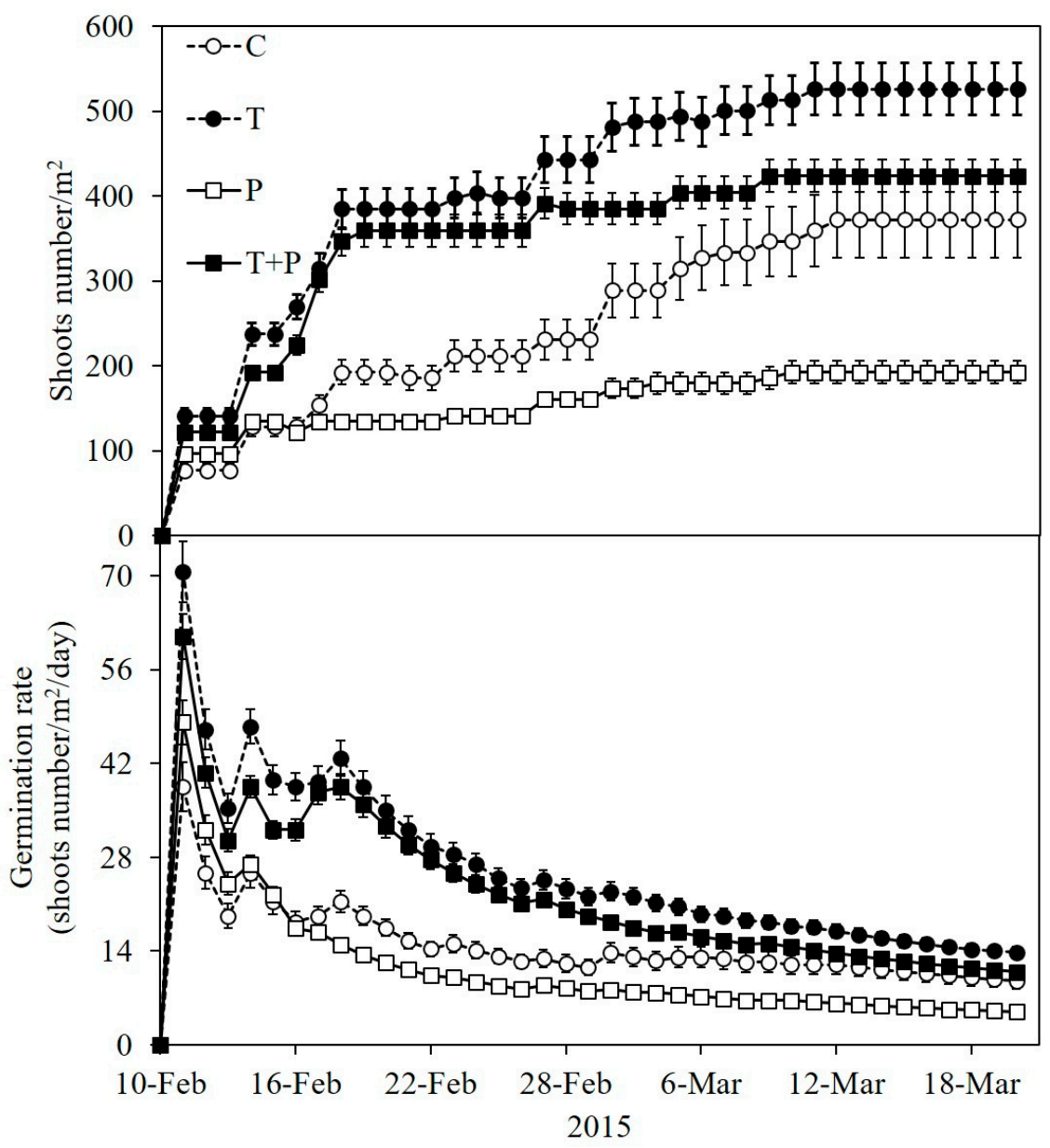

Figure 5. The average number and germination rate of P. crispus shoots during the experiment in 2015. Error bars indicate \pm standard error (SE). For abbreviations used, see Figure 2.

\section{Discussion}

\subsection{Warming and Phosphorus Addition Effect on Seedlings Emergence of Maternal Generation}

Our study demonstrated that warming significantly accelerated the emergence of P. crispus. Temperature, among all the factors that may affect the emergence of submerged macrophytes, is of paramount importance during life cycle of plants. Some earlier studies found that warming can promote the growth of aquatic plants [8]. However, many studies have found that there is no evidence for plant phenology advance though significant warming [38,39], which means it might be species specific [40]. Our results indicated that warming can accelerate the life cycle of P. crispus. In most cases, seedlings of a certain plant emerge within the optimal temperature range [41]. Seedlings of P. crispus in this study emerged around $6^{\circ} \mathrm{C}$, as earlier found by Zhang et al. [42] that the length of P. crispus increased from 8 to $12{ }^{\circ} \mathrm{C}$, which means higher temperatures may give rise to earlier emergence to some extent [43]. Our results imply that temperature could be the most important trigger for the emergence of submerged macrophytes.

Our analyses and understandings of the reason why phosphorus addition reduced the emergence of seedlings in $\mathrm{T}+\mathrm{P}$ treatments is due to the enrichment of phosphorus in aquatic ecosystems, which is also the main reason that causes water body's eutrophication. The habitat environment of aquatic macrophyte deteriorated correlated with intensified eutrophication due to an increase in phosphorus concentrations and deteriorated underwater light environment due to increased water level, total suspended matter and Chl.a concentration [44]. During our study period, the concentrations of Chl.a was significantly higher in phosphorus addition treatments. Higher concentration of Chl.a indicated 
a larger phytoplankton biomass in water column, which resulted in a deteriorated underwater light environment. Moreover, climate warming could increase the availability of phosphorus to macrophytes [45]. High phosphorus concentration increased the competition between macrophytes and phytoplankton [46]. Warming led to a shift from a clear, macrophyte-dominated state to a turbid, phytoplankton-dominated state [17]. Finally, the emergence of P. crispus in phosphorus addition treatments was inhibited in our study period due to increased eutrophication and a deteriorated underwater light environment.

\subsection{Warming and Phosphorus Addition Effect on P. crispus Stoichiometric Properties}

Temperature increase would lead to a depression of tissue nutrient concentrations of aquatic macrophytes [47]. According to our study, nitrogen content and the C:N ratio varies significantly between temperature elevated and ambient, but carbon content did not change. Temperature is one of the major factors affecting individual physiological process. Macrophytes grown in warmer regions, need less nutrients (e.g., nitrogen, phosphorus) because of the higher efficiency of biochemical reactions than cold habitats [48]. The negative correlation between temperature and nutrients indicates that when exposed in low-temperature environment, macrophytes tend to conserve more nutrients to counteract the negative effects [47]. However, P. crispus generally stops growing at temperature above $24{ }^{\circ} \mathrm{C}$, and starts to decompose when temperature surpass $30^{\circ} \mathrm{C}$; it thrives better at low temperatures (10-20 ${ }^{\circ} \mathrm{C}$ ) [49]. In our experiment, temperature reached $30{ }^{\circ} \mathrm{C}$ (May) in $\mathrm{T}$ and $\mathrm{T}+\mathrm{P}$ treatments when $P$. crispus began to forming turions. We assume that $P$. crispus will allocate more nutrients to propagules in order to resist the adverse effects of high temperature, which was consistent with Wang et al. (unpublished data) [50] that nitrogen content in turions of P. crispus was higher in elevated treatment than in ambient treatment. Materials reserved by propagule can affect its germination [51], especially the nitrogen $(\mathrm{N})$ and carbon $(\mathrm{C})$ contents [52]. In most cases, researchers showed that a high content of nitrogen will enhance the germination of seeds [53,54]. Therefore, turion's vigor is likely to be enhanced by the increase of turions nitrogen content, which may be achieved by an adequate application of a large amount of nitrogen from parent plants. Consequently, it may be possible to improve and stabilize the establishment of P. crispus by the turions with a high nitrogen content.

\subsection{Warming and Phosphorus Addition Effect on Offspring Seedlings Emergence}

Our results demonstrated that maternal warming and phosphorus addition had a significant effect on the early life stage of offspring of P. crispus. Seedlings from warmed maternal plants emerged faster and more than those from ambient environment, while seedlings from phosphorus addition maternal plants were inhibited. Studies suggested that asexual reproduction in macrophytes may contribute to the maintenance of the current population [55]. As for P. crispus, turions are the major source of propagation. One mature plant can produce dozens of turions, and the turions consist of at least two buds covered with a hard shell. In this case, the positive response of the offspring could cause a rapid population growth in next generation as the temperature increases. Maternal warming significantly affected the number of seedlings emergence on offspring [33]. Previous studies of terrestrial plants have demonstrated warm maternal environments can cause higher germination of seeds of Arabidopsis thaliana [56] and Onopordum acanthium [57] than ambient environments. Our results are in line with those found that maternal warming can accelerate at least the early life stages of plants. For aquatic plants, water body temperature is an important influence on plant physiology and reproduction. In higher water temperature where mother plants grow, the species generally produce bigger seeds or turions than their lower water temperature congeners, possible due to a longer growing season and increased speed of seed maturation [58]. Climate warming is a global, constant phenomenon in the next century. Under this background, P. crispus can be benefited especially when in competition with those plant species which will not be affected by maternal warming, by improving plant survival rates. Earlier seedling emergence not only improves plant survival, but also expedites 
the life cycle of the species, which may lead to rapid population growth as mean temperature of water will increase in winter and spring under global warming.

\section{Conclusions}

Global warming could modify population growth via maternal environmental effects on early life histories, while increased anthropogenic nutrient inputs and a degraded underwater light climate surely result in a decrease of submerged macrophytes. These maternal effects on offspring performance may change competition and survival of early life-history stages under climate warming and eutrophication. Furthermore, selection forces on life-history traits other than germination and emergence should also be considered in order to obtain reliable predictions of individual and population performance under climate change. Thus, we hope that future studies will integrate maternal environmental effects with aquatic plant life-history traits when assessing submerged macrophytes under global warming and eutrophication.

Author Contributions: Conceptualization, M.Z. and J.X.; Methodology, M.Z. and J.X.; Software, M.Z. and C.L.; Validation, M.Z., J.X. and C.L.; Formal Analysis, M.Z., J.X. and C.L.; Investigation, C.L. and T.W.; Resources, M.Z.; Data Curation, M.Z., C.L.; Writing-Original Draft Preparation, C.L.; Writing-Review \& Editing, M.Z., J.X. and C.L.; Visualization, M.Z. and C.L.; Supervision, M.Z. and J.X.; Project Administration, M.Z.; Funding Acquisition, M.Z. and J.X.

Funding: The study was funded by the National Natural Science Foundation of China (Grant No. 31872687 and 31370473), and the Water Pollution Control and Management Project of China (Grant No. 2018ZX07208005).

Acknowledgments: We would like to thank Jinyu Huang for constructing and maintaining the temperature regulatory system.

Conflicts of Interest: The authors declare no conflict of interest.

\section{References}

1. Engelhardt, K.A.; Ritchie, M.E. Effects of macrophyte species richness on wetland ecosystem functioning and services. Nature 2001, 411, 687. [CrossRef] [PubMed]

2. Li, E.-H.; Li, W.; Liu, G.-H.; Yuan, L.-Y. The effect of different submerged macrophyte species and biomass on sediment resuspension in a shallow freshwater lake. Aquat. Bot. 2008, 88, 121-126. [CrossRef]

3. Pluntke, T.; Kozerski, H.-P. Particle trapping on leaves and on the bottom in simulated submerged plant stands. Hydrobiologia 2003, 506, 575-581. [CrossRef]

4. Van Donk, E.; van de Bund, W.J. Impact of submerged macrophytes including charophytes on phyto- and zooplankton communities: allelopathy versus other mechanisms. Aquat. Bot. 2002, 72, 261-274. [CrossRef]

5. White, J.W.C.; Houghton, J.T.; Jenkins, G.J.; Ephraums, J.J. Climate change: the ipcc scientific assessment. Report Prepared for IPCC Working Group 1. Intergovernmental Panel on Climate Change. Arct. Alp. Res. 1992, 24, 263. [CrossRef]

6. Boyero, L.; Pearson, R.G.; Gessner, M.O.; Barmuta, L.A.; Ferreira, V.; Graça, M.A.S.; Dudgeon, D.; Boulton, A.J.; Callisto, M.; Chauvet, E.; et al. A global experiment suggests climate warming will not accelerate litter decomposition in streams but might reduce carbon sequestration. Ecol. Lett. 2011, 14, $289-294$. [CrossRef] [PubMed]

7. Greig, H.S.; Kratina, P.; Thompson, P.L.; Palen, W.J.; Richardson, J.S.; Shurin, J.B. Warming, eutrophication, and predator loss amplify subsidies between aquatic and terrestrial ecosystems. Glob. Chang. Biol. 2011, 18, 504-514. [CrossRef]

8. Rooney, N.; Kalff, J. Inter-annual variation in submerged macrophyte community biomass and distribution: the influence of temperature and lake morphometry. Aquat. Bot. 2000, 68, 321-335. [CrossRef]

9. Netten, J.J.C.; Van, Z.J.; Kosten, S.; Peeters, E.T.H.M. Differential response to climatic variation of free-floating and submerged macrophytes in ditches. Freshw. Biol. 2011, 56, 1761-1768. [CrossRef]

10. Cao, J.; Ruan, H. Responses of the submerged macrophyte Vallisneria natans to elevated $\mathrm{CO}_{2}$ and temperature. Aquat. Biol. 2015, 23, 119-127. [CrossRef] 
11. Hansson, L.-A.; Nicolle, A.; Granéli, W.; Hallgren, P.; Kritzberg, E.; Persson, A.; Björk, J.; Nilsson, P.A.; Brönmark, C. Food-chain length alters community responses to global change in aquatic systems. Nat. Clim. Chang. 2012, 3, 228-233. [CrossRef]

12. Netten, J.J.; Arts, G.H.; Gylstra, R.; Van Nes, E.H.; Scheffer, M.; Roijackers, R.M. Effect of temperature and nutrients on the competition between free-floating Salvinia natans and submerged Elodea nuttallii in mesocosms. Fund. Appl. Limnol. 2010, 177, 125-132. [CrossRef]

13. Smith, V.H.; Schindler, D.W. Eutrophication science: where do we go from here? Trends Ecol. Evol. 2009, 24, 201-207. [CrossRef] [PubMed]

14. Bayley, S.E.; Prather, C.M. Do wetland lakes exhibit alternative stable states? submersed aquatic vegetation and chlorophyll in western boreal shallow lakes. Limnol. Oceanogr. 2003, 48, 2335-2345. [CrossRef]

15. Kosten, S.; Kamarainen, A.M.Y.; Jeppesen, E.; van Nes, E.H.; Peeters, E.T.; Mazzeo, N.; Søndergaard, M. Climate-related differences in the dominance of submerged macrophytes in shallow lakes. Glob. Chang. Biol. 2009, 15, 2503-2517. [CrossRef]

16. Rip, W.J.; Ouboter, M.R.L.; Los, H.J. Impact of climatic fluctuations on characeae biomass in a shallow, restored lake in the Netherlands. Hydrobiologia 2007, 584, 415-424. [CrossRef]

17. Mooij, W.M.; Janse, J.H.; De Senerpont Domis, L.N.; Hülsmann, S.; Ibelings, B.W. Predicting the effect of climate change on temperate shallow lakes with the ecosystem model pclake. Shallow Lakes Chang. World 2007, 584, 443-454.

18. Moss, B.; Mckee, D.; Atkinson, D.; Collings, S.E.; Eaton, J.W.; Gill, A.B.; Harvey, I.; Hatton, K.; Heyes, T.; Wilson, D. How important is climate? effects of warming, nutrient addition and fish on phytoplankton in shallow lake microcosms. J. Appl. Ecol. 2003, 40, 782-792. [CrossRef]

19. Özkan, K.; Jeppesen, E.; Johansson, L.S.; Beklioglu, M. The response of periphyton and submerged macrophytes to nitrogen and phosphorus loading in shallow warm lakes: A mesocosm experiment. Freshw. Biol. 2010, 55, 463-475. [CrossRef]

20. Hargeby, A.; Andersson, G.; Blindow, I.; Johansson, S. Trophic web structure in a shallow eutrophic lake during a dominance shift from phytoplankton to submerged macrophytes. Hydrobiologia 1994, 279, 83-90. [CrossRef]

21. Sayer, C.D.; Burgess, A.M.Y.; Kari, K.; Davidson, T.A.; Peglar, S.; Yang, H.; Rose, N. Long-term dynamics of submerged macrophytes and algae in a small and shallow, eutrophic lake: Implications for the stability of macrophyte-dominance. Freshw. Biol. 2010, 55, 565-583. [CrossRef]

22. Ventura, M.; Liboriussen, L.; Lauridsen, T.; Søndergaard, M.; Søndergaard, M.; Jeppesen, E. Effects of increased temperature and nutrient enrichment on the stoichiometry of primary producers and consumers in temperate shallow lakes. Freshw. Biol. 2008, 53, 1434-1452. [CrossRef]

23. An, Y.; Wan, S.; Zhou, X.; Subedar, A.A.; Wallace, L.L.; Luo, Y. Plant nitrogen concentration, use efficiency, and contents in a tallgrass prairie ecosystem under experimental warming. Glob. Chang. Biol. 2005, 11, 1733-1744. [CrossRef]

24. Hobbie, E.A.; Olszyk, D.M.; Rygiewicz, P.T.; Tingey, D.T.; Johnson, M.G. Foliar nitrogen concentrations and natural abundance of 15n suggest nitrogen allocation patterns of Douglas-fir and Mycorrhizal fungi during development in elevated carbon dioxide concentration and temperature. Tree Physiol. 2001, 21, 1113-1122. [CrossRef] [PubMed]

25. Bakker, E.S.; Nolet, B.A. Experimental evidence for enhanced top-down control of freshwater macrophytes with nutrient enrichment. Oecologia 2014, 176, 825-836. [CrossRef] [PubMed]

26. Gutierrez-Marcos, J.F.; Constância, M.; Burton, G.J. Maternal to offspring resource allocation in plants and mammals. Placenta 2012, 33, 3-10. [CrossRef] [PubMed]

27. Wolf, J.B.; Wade, M.J. What are maternal effects (and what are they not)? Philos. Trans. R. Soc. B 2009, 364, 1107-1115. [CrossRef] [PubMed]

28. Dey, S.; Proulx, S.R.; Teotónio, H. Adaptation to Temporally Fluctuating Environments by the Evolution of Maternal Effects. Plos Biol. 2015, 14.

29. Sultan, S.E.; Barton, K.; Wilczek, A.M. Contrasting patterns of transgenerational plasticity in ecologically distinct congeners. Ecology 2009, 90, 1831-1839. [CrossRef] [PubMed]

30. Hereford, J.; Moriuchi, K.S. Variation among populations of Diodia teres (rubiaceae) in environmental maternal effects. J. Evol. Biol. 2005, 18, 124-131. [CrossRef] [PubMed] 
31. Amjad, M.; Anjum, M.A.; Akhtar, N. Influence of Phosphorus and Potassium Supply to the Mother Plant on Seed Yield, Quality and Vigour in Pea. Asian J. Plant. Sci. 2004, 3, 108-113.

32. Hrdlickova, J.; Hejcman, M.; Kristalova, V.; Pavlu, V. Production, size, and germination of broad-leaved dock seeds collected from mother plants grown under different nitrogen, phosphorus, and potassium supplies. Weed Biol. Manag. 2011, 11, 190-201. [CrossRef]

33. Zhang, R.; Gallagher, R.S.; Shea, K. Maternal warming affects early life stages of an invasive thistle. Plant. Biol. 2012, 14, 783-788. [CrossRef] [PubMed]

34. Lacey, E.P.; Herr, D. Parental effects in Plantago lanceolata L. III. Measuring Parental Temperature Effects in the Field. Evolution 2000, 54, 1207-1217. [CrossRef] [PubMed]

35. Donohue, K. Completing the Cycle: Maternal Effects as the Missing Link in Plant Life Histories. Philos. Trans. R. Soc. B 2009, 364, 1059-1074. [CrossRef] [PubMed]

36. Sastroutomo, S.S. Turion formation, dormancy and germination of curly pondweed, Potamogeton crispus L. Aquat. Bot. 1981, 10, 161-173. [CrossRef]

37. Zhang, P.; Bakker, E.S.; Zhang, M.; Xu, J. Effects of warming on Potamogeton crispus growth and tissue stoichiometry in the growing season. Aquat. Bot. 2016, 128, 13-17. [CrossRef]

38. Hart, R.; Salick, J.; Ranjitkar, S.; Xu, J. Herbarium specimens show contrasting phenological responses to himalayan climate. Proc. Natl. Acad. Sci. USA 2014, 111, 10615-10619. [CrossRef] [PubMed]

39. Davis, C.C.; Willis, C.G.; Connolly, B.; Kelly, C.; Ellison, A.M. Herbarium records are reliable sources of phenological change driven by climate and provide novel insights into species' phenological cueing mechanisms. Am. J. Bot. 2015, 102, 1599-1609. [CrossRef] [PubMed]

40. Primack, R.B.; Ibáñez, I.; Higuchi, H.; Lee, S.D.; Miller-Rushing, A.J.; Wilson, A.M.; Silander, J.A. Spatial and interspecific variability in phenological responses to warming temperatures. Biol. Conserv. 2009, 142, 2569-2577. [CrossRef]

41. Finch-Savage, W.E.; Leubner-Metzger, G. Seed dormancy and the control of germination. New Phytol. 2006, 171, 501-523. [CrossRef] [PubMed]

42. Zhang, X.; Odgaard, R.; Olesen, B.; Lauridsen, T.L.; Liboriussen, L.; Søndergaard, M.; Liu, Z.; Jeppesen, E. Warming shows differential effects on late-season growth and competitive capacity of Elodea canadensis and Potamogeton crispus in shallow lakes. Inland Waters 2015, 54, 421-432. [CrossRef]

43. Tobiessen, P.; Snow, P.D. Temperature and light effects on the growth of Potamogeton crispus in collins lake, New York State. Can. J. Bot. 1984, 62, 2822-2826. [CrossRef]

44. Zhang, Y.L.; Liu, X.H.; Qin, B.Q.; Shi, K.; Deng, J.M.; Zhou, Y.Q. Aquatic vegetation in response to increased eutrophication and degraded light climate in Eastern Lake Taihu: Implications for lake ecological restoration. Sci. Rep. 2016, 6, 23867. [CrossRef] [PubMed]

45. Jiang, X.; Jin, X.; Yao, Y.; Li, L.; Wu, F. Effects of biological activity, light, temperature and oxygen on phosphorus release processes at the sediment and water interface of taihu lake, china. Water Res. 2008, 42, 2251-2259. [CrossRef] [PubMed]

46. Lacoul, P.; Freedman, B. Environmental influences on aquatic plants in freshwater ecosystems. Environ. Rev. 2006, 14, 89-136. [CrossRef]

47. Wang, Z.; Xia, C.; Yu, D.; Wu, Z. Low-temperature induced leaf elements accumulation in aquatic macrophytes across tibetan plateau. Ecol. Eng. 2015, 75, 1-8. [CrossRef]

48. Weih, M.; Karlsson, P.S. Growth response of Mountain birch to air and soil temperature: is increasing leaf-nitrogen content an acclimation to lower air temperature? New Phytol. 2001, 150, 147-155. [CrossRef]

49. Ren, J.C.; Qiao, J.R.; Dong, W.; Dai, C.L. Study on ecological habits of Potamogeton crispus and its growth in Jing-Mi cannal, Beijing. Acta Sci. Nat. Univ. Pekinensis 1997, 33, 749-755.

50. Wang, T.; Zhang, Y.T.; Li, C.; Hu, B.W.; Xu, J.; Zhang, M. Effects of maternal warming on early germination of Potamogeton crispus turions. Acta Hydrobiol. Sin. 2018, in press.

51. Fait, A.; Angelovici, R.; Less, H.; Ohad, I.; Urbanczyk-Wochniak, E.; Fernie, A.R.; Galili, G. Arabidopsis seed development and germination is associated with temporally distinct metabolic switches. Plant. Physiol. 2006, 142, 839-854. [CrossRef] [PubMed]

52. Toorop, P.E.; Campos Cuerva, R.; Begg, G.S.; Locardi, B.; Squire, G.R.; Iannetta, P.P.M. Co-adaptation of seed dormancy and flowering time in the arable weed Capsella bursa-pastoris (shepherd's purse). Ann. Bot. 2011, 109, 481-489. [CrossRef] [PubMed] 
53. Caliskan, S.; Makineci, E. Variations in carbon and nitrogen ratios and their effects on seed germination in Cupressus sempervirens populations. Scand. J. For. Res. 2014, 29, 162-169. [CrossRef]

54. Hara, Y.; Toriyama, K. Seed nitrogen accelerates the rates of germination, emergence, and establishment of rice plants. J. Soil Sci. Plant. Nut. 1998, 44, 359-366. [CrossRef]

55. Li, W. Environmental opportunities and constraints in the reproduction and dispersal of aquatic plants. Aquat. Bot. 2014, 118, 62-70. [CrossRef]

56. Schmuths, H.; Bachmann, K.; Weber, W.E.; Horres, R.; Hoffmann, M.H. Effects of preconditioning and temperature during germination of 73 natural accessions of Arabidopsis thaliana. Ann. Bot. 2006, 97, 623-634. [CrossRef] [PubMed]

57. Qaderi, M.M.; Cavers, P.B.; Hamill, A.S.; Downs, M.P.; Bernards, M.A. Maturation temperature regulates germinability and chemical constituents of scotch thistle (Onopordum acanthium) cypselas. Can. J. Bot. 2006, 84, 28-38. [CrossRef]

58. Totland, O.; Birks, H.J.B. Factors influencing inter-population variation in Ranunculus acris seed production in an alpine area of southwestern norway. Ecography 1996, 19, 269-278. [CrossRef]

(C) 2018 by the authors. Licensee MDPI, Basel, Switzerland. This article is an open access article distributed under the terms and conditions of the Creative Commons Attribution (CC BY) license (http:// creativecommons.org/licenses/by/4.0/). 